\title{
Asymmetric phase-transfer-catalyzed synthesis of five-membered cyclic gamma- Amino acid precursors
}

Article

Accepted Version

Nodes, W. J., Shankland, K., Rajkumar, S. and Cobb, A. J. A. (2010) Asymmetric phase-transfer-catalyzed synthesis of fivemembered cyclic gamma-Amino acid precursors. Synlett, 2010 (20). pp. 3011-3014. ISSN 1437-2096 doi:

https://doi.org/10.1055/s-0030-1259050 Available at https://centaur.reading.ac.uk/16160/

It is advisable to refer to the publisher's version if you intend to cite from the work. See Guidance on citing.

To link to this article DOI: http://dx.doi.org/10.1055/s-0030-1259050

Publisher: Thieme Publishing

All outputs in CentAUR are protected by Intellectual Property Rights law, including copyright law. Copyright and IPR is retained by the creators or other copyright holders. Terms and conditions for use of this material are defined in the End User Agreement.

www.reading.ac.uk/centaur 
Central Archive at the University of Reading

Reading's research outputs online 


\title{
Asymmetric Phase-Transfer-Catalyzed Synthesis of Five-Membered Cyclic $\gamma$-Amino Acid Precursors
}

\author{
Willam J. Nodes, Kenneth Shankland, Sundaram Rajkumar, Alexander J. A. Cobb* \\ School of Pharmacy, University of Reading, Whiteknights, Reading RG6 6AD, UK \\ Fax +44(118)3784638; E-mail: a.j.a.cobb@ reading.ac.uk \\ Received 4 October 2010
}

Abstract: The first example of an intramolecular enantioselective
Michael addition of nitronates onto conjugated systems utilizing a
chiral phase-transfer catalyst is described. A range of five-mem-
bered $\gamma$-nitro esters with up to three stereocentres have been pre-
pared and the relative and absolute configurations proven by
chemical and crystallographic methods. The products are rapidly
obtained and are precursors to five-membered cyclic $\gamma$-amino acids.

Key words: organocatalysis, phase transfer, intramolecular, nitronate, Michael addition

$\gamma$-Amino acids represent an important and interesting class of unnatural biomolecules - their biological activity is well known and they are used extensively in treatment of diseases of the central nervous system such as epilepsy, neuropathic pain, and anxiety. Some $\gamma$-Amino acids have also been shown to form interesting unnatural peptides with well-defined secondary structures known as foldamers. ${ }^{1}$ This exciting area of study has huge potential - not only in the possibility of gaining a deeper understanding of biomolecular structure, ${ }^{2}$ but also in the field of peptidomimetics where designed unnatural peptides might mimic the protein-protein interactions involved in various disease states. ${ }^{3}$ In spite of this promise, the development of foldamers based on $\gamma$-amino acids has not burgeoned rapidly, owing to the difficulty in accessing the appropriate monomers.

Recently, we demonstrated that the intramolecular cyclization of nitronates onto conjugated esters using bifunctional thiourea catalysts was an excellent way of gaining access to six-membered cyclically constrained $\gamma$ amino acids. ${ }^{4}$ However, when we attempted to apply our methodology to the smaller five-membered ring size, the reaction slowed down further and both the enantioselectivity and diastereoselectivity suffered dramatically (Scheme 1).

In our original proposed mechanism, we suggested that the nitronate and the carbonyl of the conjugated ester must simultaneously coordinate to the thiourea component of the organocatalyst. This might indeed go some way towards explaining the lack of effective reactivity of the five-membered systems; that is, the removal of a single carbon atom must reduce this ability for simultaneous co-

SYNLETT 2010, No. x, pp 0001-0004

Advanced online publication: xx.xx.2010

DOI: 10.1055/s-0030-xxxxx; Art ID: D26610ST

(c) Georg Thieme Verlag Stuttgart · New York

Imprimatur:

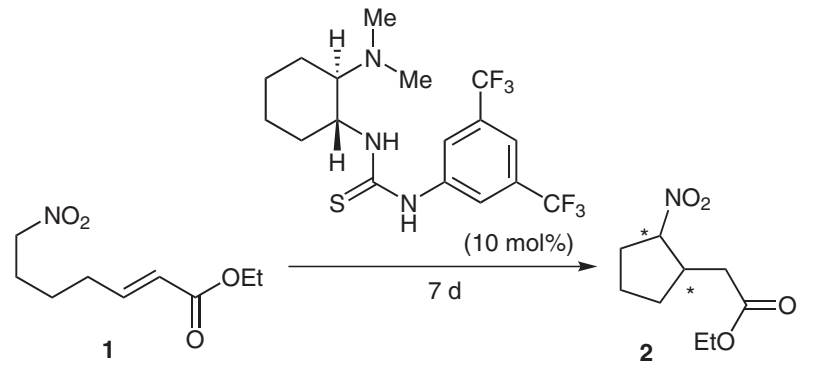

solvent $=$ THF: $61 \%$ yield, $30 \%$ ee cf. $90 \%$ ee for six-membered system

Scheme 1 Attempted synthesis of nitrocyclopentanes using the methodology described in the literature ${ }^{4}$

ordination. Another detrimental side to this process was the extended reaction times involved. Therefore, as part of our efforts to improve this reaction, we decided to turn to a different mode of catalysis and began to focus on the use of chiral phase-transfer catalysts to increase reaction speed and/or enantioselectivity.

Chiral quaternary ammonium salts have been used extensively in the synthesis of unnatural $\alpha$-amino acids. Most commonly, they have been used in the alkylation of glycine Schiff bases with reactive electrophiles such as benzyl or allyl halides. ${ }^{5}$ Michael additions of these same Schiff bases have also been achieved utilizing Michael ac-

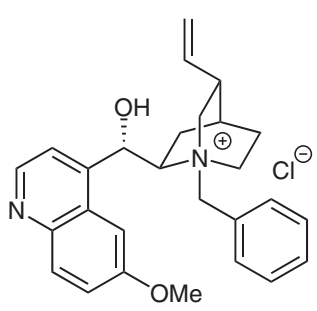

3

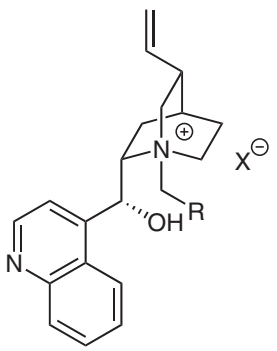

Figure 1

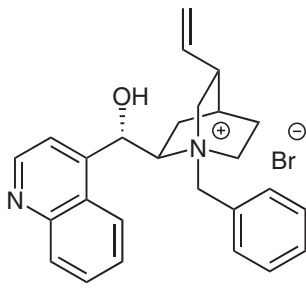

4

5: $\mathrm{R}=\mathrm{Ph} ; \mathrm{X}=\mathrm{Br}$

6: $\mathrm{R}=1$-anthrecenyl (check); $\mathrm{X}=\mathrm{Br}$

7: $\mathrm{R}=4-\mathrm{O}_{2} \mathrm{NC}_{6} \mathrm{H}_{4} ; \mathrm{X}=\mathrm{Br}$

8: $\mathrm{R}=4-\mathrm{FC}_{6} \mathrm{H}_{4} ; \mathrm{X}=\mathrm{Br}$

9: $\mathrm{R}=2,3,4-\mathrm{F}_{3} \mathrm{C}_{6} \mathrm{H}_{2} ; \mathrm{X}=\mathrm{Br}$

10: $\mathrm{R}=2-\mathrm{F}_{3} \mathrm{CC}_{6} \mathrm{H}_{4} ; \mathrm{X}=\mathrm{Br}$

11: $R=4-\mathrm{F}_{3} \mathrm{CC}_{6} \mathrm{H}_{4} ; X=\mathrm{Br}$

12: $\mathrm{R}=4-\mathrm{MeOC}_{6} \mathrm{H}_{5} ; \mathrm{X}=\mathrm{Cl}$

13: $\mathrm{R}=3,5-\left(\mathrm{F}_{3} \mathrm{C}\right)_{2} \mathrm{C}_{6} \mathrm{H}_{3} ; \mathrm{X}=\mathrm{Br}$

14: $\mathrm{R}=4-\mathrm{FC}_{6} \mathrm{H}_{4} ; \mathrm{X}=\mathrm{BF}_{4}$

15: $\mathrm{R}=4-\mathrm{F}_{3} \mathrm{CC}_{6} \mathrm{H}_{4} ; \mathrm{X}=\mathrm{BF}_{4}$ 
ceptors such as acrylonitrile ${ }^{6}$ or various conjugated ketones $^{7}$ or esters. ${ }^{8}$

The addition of nitronates to conjugated systems using quaternary ammonium salts has also been demonstrated, but where these processes have been asymmetric in nature, they have only been intermolecular ${ }^{9}$ and, although intramolecular examples exist, to the best of our knowledge, none of these are catalytic enantioselective processes. ${ }^{10}$ Herein, we report our first investigations using readily accessible cinchona alkaloids in the synthesis of five-membered cyclic $\gamma$-amino acids.

We began by focusing on the cyclization of the simplest substrate 1 (see Table 1) under phase-transfer conditions and examined the effect of base on reactivity and stereoselectivity, initially using the relatively simple and commercially available phase-transfer catalyst 3 (Figure 1).

Table 1 Cyclization of Compound 1

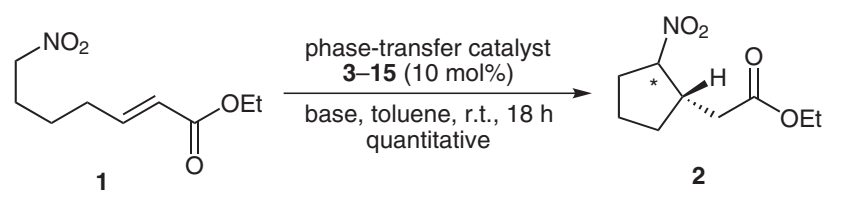

\begin{tabular}{|c|c|c|c|c|c|}
\hline Entry & Catalyst & Base & $\mathrm{dr}$ (trans) & ee $(\mathrm{m}$ & , ee (minor, \\
\hline & & (equiv) & $(c i s)^{\mathrm{a}, \mathrm{b}}$ & $\%)^{\mathrm{c}}$ & $\%)^{\mathrm{c}}$ \\
\hline 1 & 3 & $\mathrm{KOH}(0.5)$ & 4.3:1 & 28 & 28 \\
\hline 2 & 3 & $\mathrm{NaOH}(0.5)$ & $4.3: 1$ & 28 & 28 \\
\hline 3 & 3 & $\mathrm{Na}_{2} \mathrm{CO}_{3}(0.5)$ & $3.3: 1$ & 29 & 32 \\
\hline 4 & 3 & $\mathrm{Cs}_{2} \mathrm{CO}_{3}(0.5)$ & $4: 1$ & 30 & 32 \\
\hline 5 & 3 & $\mathrm{~K}_{2} \mathrm{CO}_{3}(0.5)$ & $5: 1$ & 30 & 30 \\
\hline 6 & 3 & $\mathrm{~K}_{2} \mathrm{CO}_{3}(0.2)$ & $2.7: 1$ & 28 & 32 \\
\hline 7 & 4 & $\mathrm{~K}_{2} \mathrm{CO}_{3}(0.2)$ & $3.5: 1$ & 32 & 27 \\
\hline 8 & 5 & $\mathrm{~K}_{2} \mathrm{CO}_{3}(0.2)$ & $4: 1$ & 32 & 32 \\
\hline 9 & 6 & $\mathrm{~K}_{2} \mathrm{CO}_{3}(0.2)$ & $4.3: 1$ & 20 & 20 \\
\hline 10 & 7 & $\mathrm{~K}_{2} \mathrm{CO}_{3}(0.2)$ & $2: 3$ & 30 & 32 \\
\hline 11 & 8 & $\mathrm{~K}_{2} \mathrm{CO}_{3}(0.2)$ & 4.6:1 & 34 & 33 \\
\hline 12 & 9 & $\mathrm{~K}_{2} \mathrm{CO}_{3}(0.2)$ & $3.8: 1$ & 18 & 18 \\
\hline 13 & 10 & $\mathrm{~K}_{2} \mathrm{CO}_{3}(0.2)$ & $4.3: 1$ & 8 & 8 \\
\hline 14 & 11 & $\mathrm{~K}_{2} \mathrm{CO}_{3}(0.2)$ & $2: 3$ & 50 & 30 \\
\hline 15 & 12 & $\mathrm{~K}_{2} \mathrm{CO}_{3}(0.2)$ & 4.6:1 & 24 & 24 \\
\hline 16 & 13 & $\mathrm{~K}_{2} \mathrm{CO}_{3}(0.2)$ & $3.5: 1$ & 32 & 30 \\
\hline 17 & 14 & $\mathrm{~K}_{2} \mathrm{CO}_{3}(0.2)$ & $2.8: 1$ & 36 & 26 \\
\hline 18 & 15 & $\mathrm{~K}_{2} \mathrm{CO}_{3}(0.2)$ & $2.6: 1$ & 46 & 32 \\
\hline
\end{tabular}

${ }^{a}$ In all but two cases (entries 10 and 14), the trans system predominated.

${ }^{\mathrm{b}}$ Determined by ${ }^{1} \mathrm{H}$ NMR spectroscopy.

${ }^{\mathrm{c}}$ Determined by chiral HPLC.
Using toluene as solvent, we were delighted to find that this screening reaction occurred very rapidly (in general, TLC showed complete consumption of starting material after just two hours) to give the trans-cyclized ${ }^{11}$ product 2 in quantitative yield and moderate enantioselectivity favoring the $1 S, 2 R$ isomer. ${ }^{12}$ Variation of base - which could be used in substoichiometric amounts - appeared to have little effect on the enantioselectivity of the reaction process, with potassium carbonate seeming to give only a slight improvement on diastereoselectivity. As expected, the reaction failed to proceed in the absence of either base or catalyst. Furthermore, lowering the temperature appeared to suppress the reaction altogether. We therefore proceeded with potassium carbonate as base and examined a large range of different catalyst structures in an effort to focus on the improvement of enantioselectivity. Three varieties of cinchona alkaloid were examined $(\mathbf{3}, \mathbf{4}$, and 5; entries 6, 7, and 8) - each $\mathrm{N}$-alkylated with a benzyl group. Each one gave excellent conversion, but the best balance between enantioselectivity and diastereoselectivity came from the use of catalyst structure $\mathbf{5}$, and, as a consequence, we used this framework to investigate the effect of N-alkylation upon enantio- and diastereocontrol.

A variety of aryl bromides was utilized, each with varying electronic properties and/or counterions. As might be expected, it was this variation in $\mathrm{N}$-alkylation that had a greater effect upon enantioselectivity. In most cases, the trans system was favored..$^{11}$ The use of larger counterions in an attempt to generate a less tightly associated ion pair did not improve reactivity. In this screen, it was catalyst 11 under the conditions described in entry 14, that gave the highest enantioselectivity and was therefore the one we chose to use in a substrate screen. Having identified this catalyst, a solvent screen was conducted and indeed toluene was found to be the solvent which gave greatest enantioselectivity (Table 2).

We therefore synthesized a range of cyclization precursors including some which would generate three new stereogenic centers (Table 2) and subjected them to catalyst

Table 2 Selected Results from Solvent Optimization

\begin{tabular}{|c|c|c|c|c|c|}
\hline \multirow[b]{2}{*}{ Entry } & \multirow[b]{2}{*}{ Solvent } & \multicolumn{2}{|c|}{$\frac{11(10 \text { mol\% })}{\longrightarrow} \underset{\begin{array}{c}\mathrm{K}_{2} \mathrm{CO}_{3}(0.2 \text { equiv }) \\
\text { solvent, r.t. } \\
18 \mathrm{~h}\end{array}}{\longrightarrow}$} & $\sum_{\text {EtO }}^{\mathrm{NO}_{2}}{ }^{\mathrm{H}}=\mathrm{O}$ & \\
\hline & & $\begin{array}{l}\text { Yield } \\
(\%)\end{array}$ & $\begin{array}{l}\mathrm{dr} \\
(\text { trans } / \text { cis })^{\mathrm{a}}\end{array}$ & $\begin{array}{l}\text { ee } \\
\text { (major, } \%)\end{array}$ & $\begin{array}{l}\text { ee } \\
\text { b (minor, \% }\end{array}$ \\
\hline 1 & $\mathrm{PhMe}$ & $>99$ & $2: 3$ & 50 & 30 \\
\hline 2 & $\mathrm{CH}_{2} \mathrm{Cl}_{2}$ & $>99$ & $5: 1$ & 26 & 26 \\
\hline 3 & THF & $>99$ & $5: 1$ & 30 & 30 \\
\hline 4 & $\mathrm{MeCN}$ & $>99$ & $5: 1$ & 4 & 4 \\
\hline 5 & $\mathrm{H}_{2} \mathrm{O}$ & 38 & $4: 1$ & 4 & 4 \\
\hline
\end{tabular}

${ }^{\text {a }}$ Determined by ${ }^{1} \mathrm{H}$ NMR spectroscopy.

${ }^{\mathrm{b}}$ Determined by chiral HPLC. 


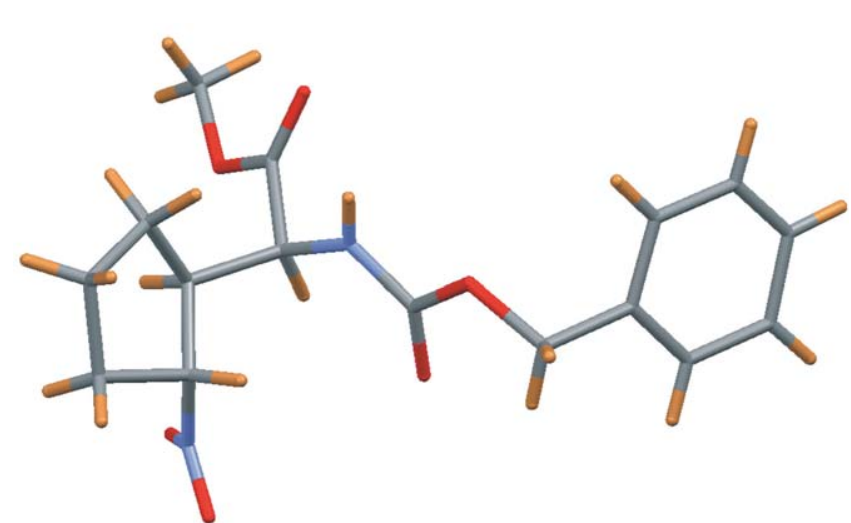

Figure 2 X-ray crystal structure of $\mathbf{2 2}^{14}$

$11(10 \mathrm{~mol} \%)$, potassium carbonate $(20 \mathrm{~mol} \%)$ in toluene at room temperature over 18 hours (Table 3$).{ }^{13}$ The substrate scope showed that the methodology was applicable to the synthesis of a range of substrates, including the fluorine-containing analogue $\mathbf{2 1}$ and a CBz-protected analogue 22. Interestingly, although the diastereoselectivity was generally moderate, in all cases it was the trans isomer that was favored and not the cis product as was found in the screening reaction. In some cases, substitution of the conjugated ester led to decreased yields.

The relative configuration was confirmed by single crystal analysis of the $N$-CBz-protected product 22 showing the trans relationship and the configuration of the third stereogenic center (Figure 2).

Table 3 Substrate Scope

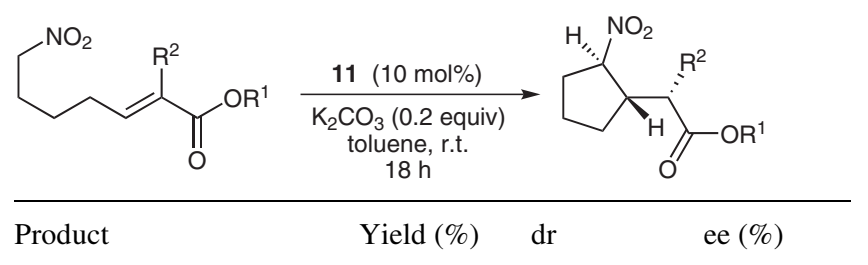<smiles>O=C(CC1CCCC1[N+](=O)[O-])OCc1ccccc1</smiles>

16<smiles>CCOC(=O)C[C@]1(C)CCC[C@H]1[N+](=O)[O-]</smiles>

17<smiles>CCOC(=O)[C@H](Cc1ccccc1)[C@H]1CCC[C@H]1[N+](=O)[O-]</smiles>

Table 3 Substrate Scope (continued)

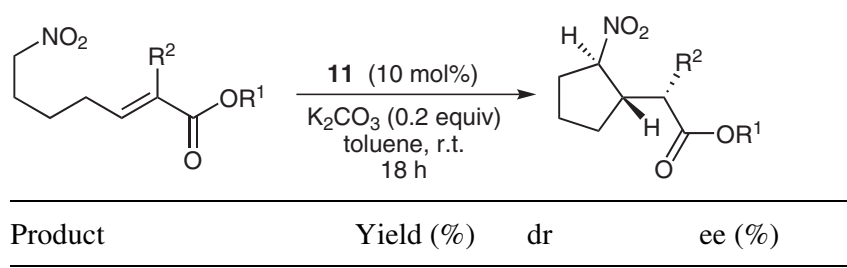<smiles>O=C(OCc1ccccc1)[C@H](Cc1ccccc1)[C@H]1CCC[C@H]1[N+](=O)[O-]</smiles>

19<smiles>CCOC(=O)[C@H](C[14CH3])[C@H]1CCC[C@H]1[N+](=O)[O-]</smiles>

20<smiles>CCOC(=O)[C@H](F)[C@H]1CCC[C@H]1[N+](=O)[O-]</smiles>

21<smiles>COC(=O)C[C@H](NC(=O)OCc1ccccc1)C1CCC[C@H]1[N+](=O)[O-]</smiles>

22<smiles>CCOC(=O)C(c1ccccc1)[C@H]1CCC[C@H]1[N+](=O)[O-]</smiles>

23<smiles>CCOC(=O)C[C@]1([N+](=O)[O-])CCC[C@H]1[N+](=O)[O-]</smiles>

2

${ }^{\text {a }}$ The dr determined by ${ }^{1} \mathrm{H}$ NMR.

${ }^{\mathrm{b}}$ The ee determined by chiral HPLC.

${ }^{\mathrm{c}}$ Relative stereochemistry assigned by analogy to compound $\mathbf{2 2}$ crystal structure (see Figure 2).

${ }^{\mathrm{d}}$ Absolute stereochemistry assigned as described in ref. 12.

In conclusion, we have, to the best of our knowledge, demonstrated the first use of chiral phase-transfer catalysts in the enantioselective, intramolecular reaction of a nitronate onto a conjugated system, and have generated useful five-membered systems that are precursors to $\gamma$ amino acids. As with other reactions involving chiral ammonium salts and nitronates, it is assumed that the enantioselectivity originates from an association between the positive charge of the catalyst and the negative charge of the nitronate. Although the enantioselectivities are relatively low, this work demonstrates that it is possible to confer some stereoselectivity on this system using phase- 
transfer catalysis - something which had not been previously achieved. As such, we are currently pursuing improved phase-transfer catalytic systems and conditions to increase the enantioselectivity of these $\gamma$-amino acid precursors which we ultimately intend to utilize in future foldamer studies.

\section{Acknowledgment}

We thank the EPSRC (for funding to W.J.N. Grant No : EP/ D070112/1) and the Felix Foundation (for funding to R.S.).

\section{References and Notes}

(1) (a) Gellman, S. H. Acc. Chem. Res. 1998, 31, 173. (b) Guo, L.; Almeida, A. M.; Zhang, W.; Reidenbach, A. G.; Choi, S. H.; Guzei, I. A.; Gellman, S. H. J. Am. Chem. Soc. 2010 , 132, 7868. (c) Guo, L.; Chi, Y. G.; Almeida, A. M.; Guzei, I. A.; Parker, B. K.; Gellman, S. H. J. Am. Chem. Soc. 2009, $131,16018$.

(2) (a) Cheng, R. P.; Gellman, S. H.; DeGrado, W. F. Chem. Rev. 2001, 101, 3219. (b) Hill, D. J.; Mio, M. J.; Prince, R. B.; Hughes, T. S.; Moore, J. S. Chem. Rev. 2001, 101, 3893. (c) Seebach, D.; Beck, A. K.; Bierbaum, D. J. Chemistry \& Biodiversity 2004, 1, 1111. (d) Seebach, D.; Gardiner, J. Acc. Chem. Res. 2008, 41, 1366. (e) Ghosh, A. K.; Bilcer, G.; Schiltz, G. Synthesis 2001, 2203. (f) List, B.; Castello, C. Synlett 2001, 1687.

(3) See, for example: (a) Bautista, A. D.; Appelbaum, J. S.; Craig, C. J.; Michel, J.; Schepartz, A. J. Am. Chem. Soc. 2010, 132, 2904. (b) Horne, W. S.; Boersma, M. D.; Windsor, M. A.; Gellman, S. H. Angew. Chem. Int. Ed. 2008, 47, 2853. (c) Murray, J. K.; Gellman, S. H. Biopolymers 2007, 88, 657. (d) Sadowsky, J. D.; Fairlie, W. D.; Hadley, E. B.; Lee, H. S.; Umezawa, N.; Nikolovska-Coleska, Z.; Wang, S. M.; Huang, D. C. S.; Tomita, Y.; Gellman, S. H. J. Am. Chem. Soc. 2007, 129, 139.

(4) Nodes, W. J.; Nutt, D. R.; Chippindale, A. M.; Cobb, A. J. A. J. Am. Chem. Soc. 2009, 131, 16016; for an excellent alternative method, see ref. 1c.

(5) For an excellent review, see : Hashimoto, T.; Maruoka, K. Chem. Rev. 2007, 107, 5656.

(6) Zhang, F.-Y.; Corey, E. J. Org. Lett. 2000, 2, 1097.

(7) Lygo, B.; Allbutt, B.; Kirton, E. H. M. Tetrahedron Lett. 2005, 46, 4461.

(8) (a) Shibuguchi, T.; Fukuta, Y.; Akachi, Y.; Sekine, A.; Ohshima, T.; Shibasaki, M. Tetrahedron Lett. 2002, 43, 9539. (b) Ohshima, T.; Shibuguchi, T.; Fukuta, Y.; Shibasaki, M. Tetrahedron 2004, 60, 7743.
(9) (a) Ooi, T.; Fujioka, S.; Maruoka, K. J. Am. Chem. Soc. 2004, 126, 11790. (b) Ooi, T.; Takada, S.; Fujioka, S.; Maruoka, K. Org. Lett. 2005, 7, 5143.

(10) (a) Marsh, G. P.; Parsons, P. J.; McCarthy, C.; Cornique, X. G. Org. Lett. 2007, 9, 2613. (b) Yasuhara, T.; Nishimura, K.; Osafune, E.; Muraoka, O.; Kiyoshi, T. Chem. Pharm. Bull. 2004, 52, 1109.

(11) Assigned both by comparison to the ${ }^{1} \mathrm{H}$ NMR of a related compound (see ref. 10a) and by analogous assignment of the proton signal from the exclusively trans crystals of compound 22 (as shown by X-ray crystallography).

(12) This was determined by Nef reaction of the product to form the $\alpha$-substituted ketone (Scheme 2) and the resulting optical rotation compared to the literature values, see: Kerr, M. S.; Read de Alaniz, J.; Rovis, T. J. Am. Chem. Soc. 2002, 124, 10298.<smiles>CCOC(=O)C[C@H]1CCCC1[N+](=O)[O-]</smiles><smiles>CCOC(=O)C[C@@H]1C(=O)CC[C@@H]1CC(=O)OCC</smiles>

Scheme 2

(13) Typical Procedure for Organocatalytic Cyclization Ethyl 2-[(1S,2R)-2-nitrocyclopentyl]acetate(2) To a solution of $(E)$-ethyl-7-nitrohept-2-enoate $(\mathbf{1}, 50.3 \mathrm{mg}$, $0.25 \mathrm{mmol})$ in toluene $(3 \mathrm{~mL})$ was added phase-transfer catalyst $11(10 \mathrm{~mol} \%)$ and $\mathrm{K}_{2} \mathrm{CO}_{3}(7 \mathrm{mg}, 0.05 \mathrm{mmol})$. The resulting solution was stirred for $18 \mathrm{~h}$ at $23{ }^{\circ} \mathrm{C}$. After this time, the solvent was removed under reduced pressure to give a pale yellow oil that was subjected to flash column chromatography $\left(\mathrm{SiO}_{2} ; \mathrm{Et}_{2} \mathrm{O}\right.$-hexane, 1:4). The resulting colourless oil ( $50.3 \mathrm{mg}, 0.25 \mathrm{mmol}$, quant.) was analyzed by chiral HPLC analysis [Chiralcel OD; $0.46 \mathrm{~cm} \varnothing \times 25 \mathrm{~cm}$; hexane-propan-2-ol (96:4); $1 \mathrm{~mL} \mathrm{~min}^{-1} ; t_{\mathrm{R}}$ (major diastereomer $)=7.06 \mathrm{~min}, 7.63 \mathrm{~min} ; t_{\mathrm{R}}($ minor diastereomer $)=8.03 \mathrm{~min}, 8.69 \mathrm{~min}] .[\alpha]_{\mathrm{D}}-3.1\left(c 1, \mathrm{CHCl}_{3}\right)$. ${ }^{1} \mathrm{H} \mathrm{NMR}\left(400 \mathrm{MHz}, \mathrm{CDCl}_{3}\right): 1.24-1.28(3 \mathrm{H}, J=7.2 \mathrm{~Hz}$, $\left.\mathrm{CH}_{3}\right), 1.35-2.37(6 \mathrm{H}$, cyclopent $-\mathrm{H}), 2.42(2 \mathrm{H}, \mathrm{m}$, $\left.\mathrm{CH}_{2} \mathrm{CO}_{2} \mathrm{Et}\right), 2.91\left(1 \mathrm{H}\right.$, hex, $\left.J=8.8 \mathrm{~Hz}, \mathrm{CHCH}_{2} \mathrm{CO}_{2} \mathrm{Et}\right), 4.14$ $\left(2 \mathrm{H}, \mathrm{q}, J=7.2 \mathrm{~Hz}, \mathrm{CH}_{2} \mathrm{CH}_{3}\right), 4.81\left(1 \mathrm{H}, \mathrm{m}, \mathrm{CHNO}_{2}\right)$ [NB: the $1 S, 2 S$ signal appears as a multiplet at $\delta=5.01]$. IR: 2979 , 1732, 1547, 1373, 1269, 1187, 1028, 913, 734, $648 \mathrm{~cm}^{-1}$. HRMS: $m / z$ calcd for $\mathrm{C}_{9} \mathrm{H}_{15} \mathrm{NO}_{4} \mathrm{Na}^{+}: 224.0893$; found: 224.0894.

(14) X-ray crystal structural information (CCDC 789178) available from the Cambridge Crystallographic Data Centre (CCDC) at http://www.ccdc.cam.ac.uk.

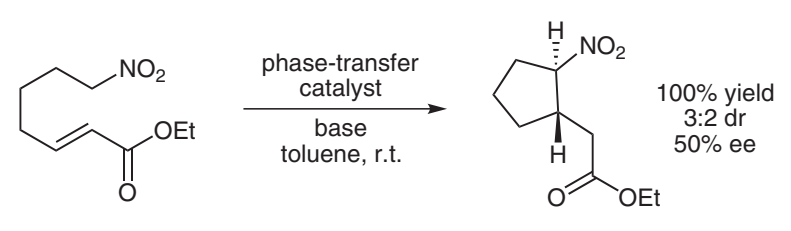

graphical abstract 